\title{
Botany, pharmacology and conservation status of wonder flower: Neelakurinji (Strobilanthes kunthiana (Nees) T. Anderson ex Benth)
}

\author{
Soumen Bera ${ }^{1 *}$, Sibsankar Das ${ }^{1}$ and Dharmadas Kalindi ${ }^{2}$
}

\begin{abstract}
Strobilanthes kunthiana (Nees) T. Anderson ex Benth locally known as Neelakurinji is an endemic to Western Ghat, India and belongs to the Acanthaceae family. It has a unique flowering pattern to bloom every 12 years. The objective of this review is to highlight the taxonomy, distribution, ecology, biology, pharmacological properties, and conservation status of Strobilanthes kunthiana. The plant S. kunthiana is a rich source of pharmacological constituents and can act as herbal alternatives for various disorders. This review discusses the unique botany specifically the flowering pattern for in-depth study to conserve not only for tourism but also for exploring its pharmacological properties and usefulness in apiary. Finally, this review highlights the potential research areas that should be interlinked with promotion of tourism with Neelakurinji attraction as well as its potential use in apiary.
\end{abstract}

Keywords: Neelakurinji, Strobilanthes kunthiana, Biology, Pharmacology, Masting

\section{Introduction}

India is a rich source of medicinal plants, which includes about 8000 species of known medicinal plants and about more than 2000 species having huge potentiality for Ayurvedic, Unani, and Siddha medicines but most of them are unexplored chemically and pharmacologically for their use medicinally (Guptha et al. 2005). The natural compounds extracted from plants used as alternative medicines to play impactful roles in the wellness of general people throughout the world. Plants have provided different amazing medicinal agents, natural products as the source of all drugs to the human race (Balandrin et al. 1993). Though lots of plants are explored for medicinal purposes, some underutilized plants still need to be explored for the same purpose. Neelakurinji is well known to possess both ornamental and medicinal properties. This

\footnotetext{
* Correspondence: soumen.bckv@gmail.com

${ }^{1}$ College of Agriculture, Extended Campus of Bidhan Chandra Krishi

Viswavidyalaya, Purba Bardhaman, West Bengal 713101, India

Full list of author information is available at the end of the article
}

plant is famous for periodical blooming only once in every 12 years (Augustine, 2008). This plant throws a wonderful visual treat with blue flowers bloom in a cluster in several branches. At maturity, its light blue color flower changes to purple bluish. This rare to see plant is present in the valleys of Western Ghats making the place an attractive tourist place. The objective of this review is to highlight botany, pharmacological properties, and conservation status of Neelakurinji. The review discussed the taxonomical, ecological, biological, pharmacological, and conservationrelated literatures for the organized repository for its further in-depth research and policymaking in tourism and apiary. Finally, this review discusses potential research focus areas on Neelakurinji flowering biology that should be interlinked for efficient use of natural scenic attraction as well as its potential use in the apiary.

\section{Taxonomy}

Kingdom: Plantae

Sub-kingdom: Phanerogamia 
Division: Angiospermia

Class: Eudicots

Sub-class: Asterids

Order: Lamiales

Family: Acanthaceae

Genus: Strobilanthe

Botanical name: Strobilanthes Kunthianus Nees T Anders

Synonyms: Strobilanthes Nilgirianthsis, Phlebophyllum Kunthianus, Ruellia kunthiana, Phlebophyllum angustifolium

Vernacular names: Tamil and Malayalam-Neelakurinji, Hindi-Kurinji

"The name Strobilanthes is derived from the Latin words 'strobilos' meaning cone and 'anthos' meaning flower or shoot. Christian Gottfried Daniel Nees von Esenbeck scientifically described the plant belongs to the genus Strobilanthes in India in the 19th century" [Anonymous I 1985; Anonymous II 2002]. The flowering plant of the species belongs to the Acanthaceae family. The plant blooms after a long interval belongs to the Genus Strobilanthes. Some species of Strobilanthes genus produce flowers yearly; some are plietesials in nature (Bremekamp 1944), with 8-16 years of cycle (Preethi and Suseem 2014). The genus Strobilanthes Blume consists of about 450 species (Mabberley 2017) and is restricted to the hills of tropical Asia. In India, it is represented by about 148 species (Karthikeyan et al. 2009), of which 72 species are endemic (Singh and Diwakar 2007), the diversity occurring in two regions, viz. the Eastern Himalayas and the Western Ghats. In Peninsular India, about 60 species have been reported (Venu 2006), of which 48 species are endemic (Singh and Diwakar 2007).

\section{Origin}

The origin of this species is Asia. It is native mostly to tropical Asia and Madagascar, but it extends to north temperate regions of Asia (Preethi and Suseem 2014).

\section{Habitat}

On bare slopes, ravines and edges of moist deciduous forests, etc. Strobilanthes kunthianus (Nees)T. Anders. is an endemic undershrub that grows above $1800 \mathrm{~m}$ in the sholas of the Western Ghats (Augustine Jomy 2018). Plants which bloom like Neelakurinji, i.e., at long intervals are called plietesials.

\section{Etymology}

The species is named after German Botanist, Karl (Carl) Sigismund Kunth (1788-1850). Initially, Nathaniel Wallich (1830) proposed the species epithet "kunthiana" in his catalog as Ruellia kunthiana.

\section{Distribution}

Tropical South and South East Asia are hotspots for Strobilanthes and individual Strobilanthes species are confined to isolated areas. While more than 300 Nelu plant species in which various colorful flowers bloom have spread in Asian countries, more than half of them have been confined to Indian sub-continent (Rajapakse et al. 2018). It is endemic to Western Ghats, India (Karnataka, Kerala, and Tamil Nadu) (Singh and Arigela 2019; Fig. 1). This shrub grows profusely in the Shola forest of Western Ghats, India (Paulsamy et al. 2007; Moylan et al. 2004) at 1300-2400 m above MSL.

\section{Morphology}

S. kunthiana is a small undershrub with a height of 30 to $60 \mathrm{~cm}$; sometimes under congenial conditions, it can grow beyond $2 \mathrm{~m}$ (Fig. 2). Neelakurinji is an important understory component of tropical evergreen forest (Bhat and Murali 2001). Morphological information is reported in an organized way in Table 1.

Strobilanthes kunthiana is readily distinguished from other members of the group by the farinose indumentum on the lower leaf surface. It is perhaps the bestknown species of Strobilanthes and its semelparous life event is well recorded with mass flowering incidents documented every 12 years since 1838 (Robinson 1935; Matthew 1971). Mass flowering events of S. kunthiana were landmarks in the lives of the hill tribes of the Western Ghats (Matthew 1971) and continue to generate significant popular interest. The name Nilgiris (Blue Mountains) may be attributed to the mass flowering of this species. Whilst most plants are in flower during the twelfth year of the cycle, some flowering occurs in the years before and after the main bloom (Matthew 1971).

\section{Plant biology}

The shrubby species of Strobilanthes are hapaxanth or monocarpic or semelparous (Daniel 2006; Sharma and Kuriakose Gand Shivanna 2008). These Strobilanthes species spend all of their strength and vitality at the end of life span for massive flowering and fruiting because they have only one chance to reproduce. The different shrubby species of Strobilanthes grow vegetatively for 3 to 15 years and attains 1 to $7 \mathrm{~m}$ height. They reach the reproductive stage in between 4 and 16 years at the end of their life span, burst into synchronized blooming, and cover the entire hill range or the area where they occur. The capsules mature and dehisce in 1 or 2 months after profuse flowering, then they wither and die off (Singh and Arigela 2019).

S. kuntiana blooms as 'synchronized flowering', i.e., individual plant species flowers in a group in a certain geographical area within the same time period (McDonald and Kwong 2005). Masting or mast seeding is 


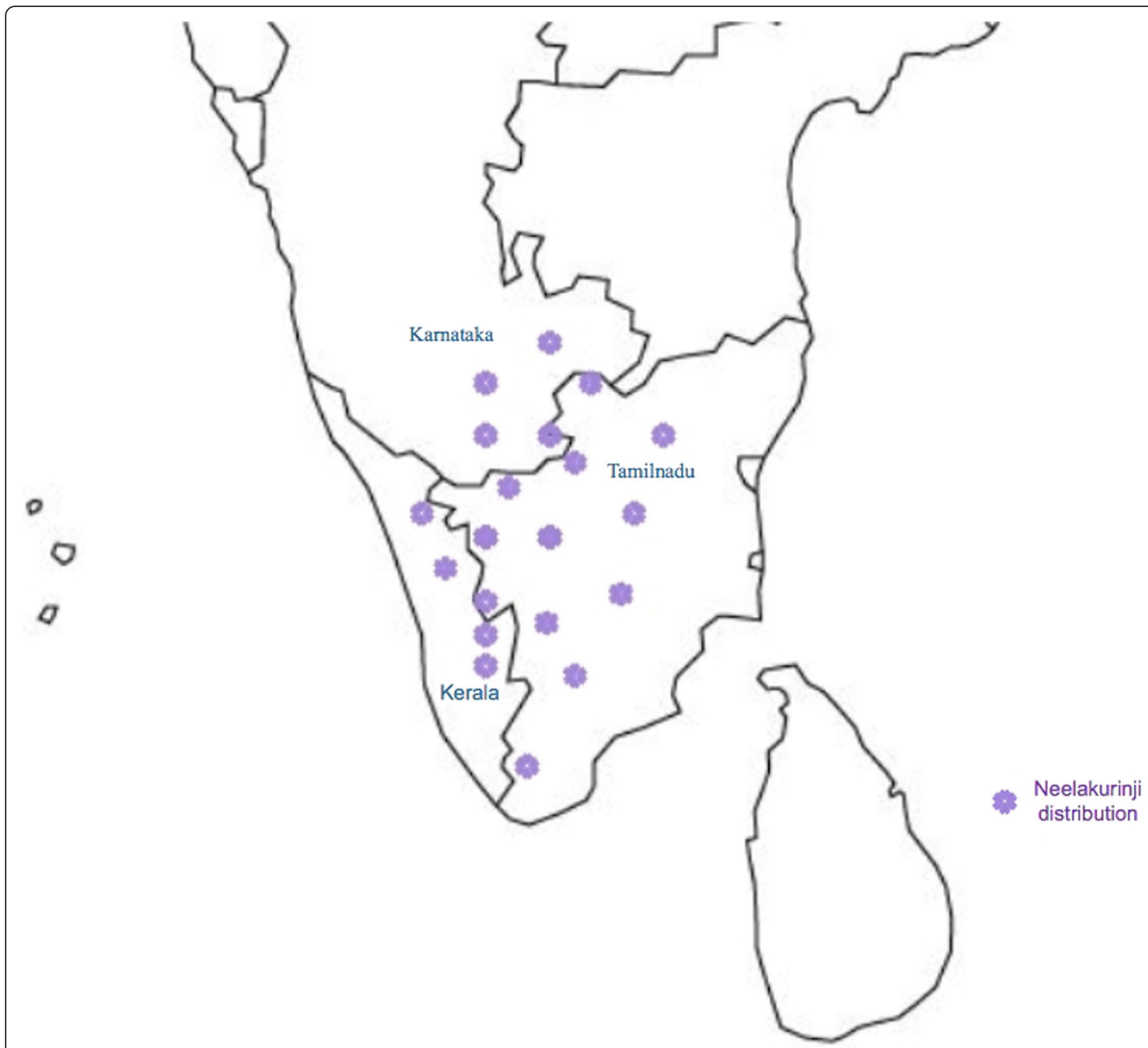

Fig. 1 Distribution of Neelakurinji (Strobilanthes Kunthianus Nees T Anders.) (Photograph is not in scale) (Source: unpublished photograph of Soumen Bera)

defined as the production of huge seeds within a particular time in an area. Masting occurs only in monocarpic species. Within a short masting period, a long vegetative phase is required to gather sufficient resources to produce a huge number of flowers and seeds. Plants with longer reproductive cycles obtain an evolutionary edge in higher survival ability compared with annual plants (Tsvuura et al. 2011). For the survival of the offspring, parent plants improve the availability of resources (space, light requirement, nutrition, etc.) after death.

Tsvuura et al. (2011) illustrated three hypotheses to report the evolutionary importance of synchronized flowering and masting of Strobilanthes kunthianus. (I) The outcrossing hypothesis signifies that cross-pollination is increased by synchronous flowering with large visual display. Diversity within the species is facilitated by crosspollination. As a result, the parent plants produce highquality seeds and seedlings with high vigor. (II) The predator satiation hypothesis suggests that perennial species produce more seeds due to synchronous production. Seed predators can consume seeds during masting years, which will not affect the next generation significantly and die during the non-seeding years. Predator satiation can be termed as an anti-predator adaptation. Individual plant species escapes easily from seed predator due to masting. (III) A third hypothesis proposes that monocarpic species display reproductive synchrony due to interspecific competition. Due to synchronized mass 


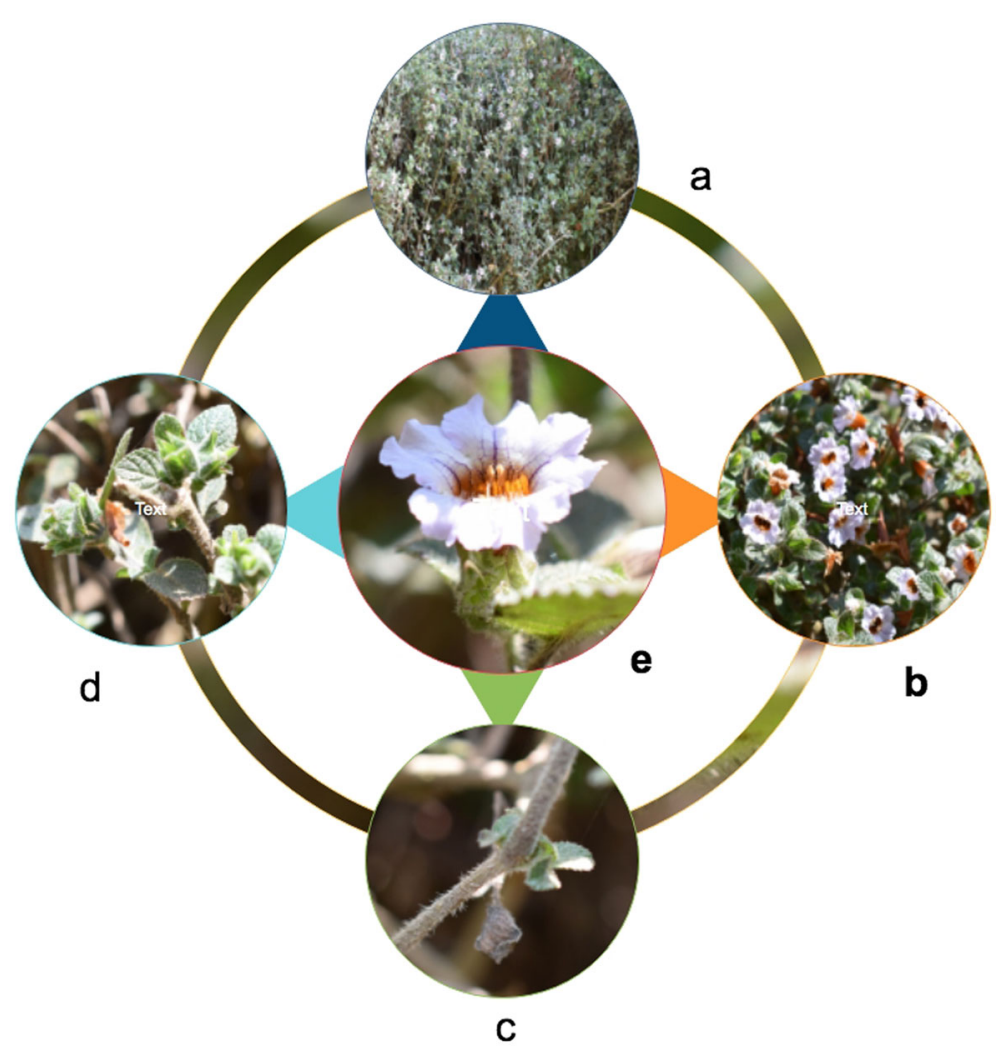

Fig. 2 Salient botanical features of Neelakurinji (Strobilanthes Kunthianus Nees T Anders). a Full-grown bushy shrub, b flower-bearing shrub, c stems with glabrous to sparsely pubescent barks, d elliptic-ovate with stout hairs with subentire to prominently serrated leaves, e pale blue or pale lilac or mauve flower (Photographs are not in scale) (Source: unpublished photographs of Soumen Bera)

Table 1 Morphological characteristics of S. kunthiana (Nees) T. Anders

\begin{tabular}{|c|c|c|}
\hline $\begin{array}{l}\text { Sr. } \\
\text { no }\end{array}$ & Characters & S. kunthiana (Nees) T. Anders \\
\hline 1 & Habit & $\begin{array}{l}\text { Bushy shrub, } 0.75-2 \mathrm{~m} \text { high, branches stout in stray clumps or gregarious, glabrous, erect, rigid, quadrangular; nodes prominent, } \\
\text { sparsely lenticellate, usually with light purplish tinge, usually angular or quadrangular upwards. Stem glabrous to sparsely } \\
\text { pubescent, usually only so in the grooves and on nodes; lenticels and leaf scars sometimes prominent (Venu 2006; Singh and } \\
\text { Arigela 2019; Carine et al. 2004; Augustine et al. 2017). }\end{array}$ \\
\hline 2 & Leaves & $\begin{array}{l}\text { Leaves elliptic-ovate, } 2.5-8 \times 1.5-4 \mathrm{~cm} \text {, acute at base, crenate-serrate at margin, apex very short acuminate; coriaceous, scabrid } \\
\text { above, white-villous between veins beneath; veins } 4-10 \text { pairs, both primary and secondary veins prominent on abaxial surface, } \\
\text { somewhat less so on adaxial surface; petiole } 0-5.4 \mathrm{~mm} \text { long, glabrous or with stout tapering hairs, especially along margins, } \\
\text { symmetrical; margins subentire to prominently serrate; abaxial surface sparsely to densely covered with a white farinose indu- } \\
\text { mentum, adaxial surface glabrous or sparsely covered with stout tapering hairs (Venu 2006; Singh and Arigela 2019; Carine et al. } \\
\text { 2004; Augustine et al. 2017). }\end{array}$ \\
\hline 3 & Inflorescence & $\begin{array}{l}\text { The inflorescence spike branched or unbranched with many flowers. Spikes in upper axils and terminal, 3-10 cm long, } \\
\text { uninterrupted, sometimes branched, white tomentose, subtended by leafy bracts; }\end{array}$ \\
\hline 4 & Bract & Bracts $1-1.5 \mathrm{~cm}$ long, elliptic-ovate, white villous, midrib not prominent. \\
\hline 5 & Bracteole & Lanceolate, $10 \mathrm{~mm}$ long, shorter than calyx, floccose at margin and middle, midrib not prominent. \\
\hline 6 & Calyx & Lobes 10-14 mm long, divided almost half from the base, floccose-villous, linear-lanceolate (Singh and Arigela 2019). \\
\hline 7 & Corolla & $\begin{array}{l}\text { Corolla } 2-3 \mathrm{~cm} \text { long, somewhat campanulate, pale blue or pale lilac or mauve, nerves darker, pubescent outside, hairy inside at } \\
\text { nectar guide area; lobes 5, orbicular or suborbicular, upper margin undulate. }\end{array}$ \\
\hline 8 & Androecium & Staminal filaments not grooved, pilose hispid. \\
\hline 9 & Pollen & Ellipsoidal, $60-86 \times 40-53 \mu \mathrm{m}, 3$-zonoporate pseudocolpi 5 in each mesocolpium, ridges $2.19 \mu \mathrm{m}$ broad \\
\hline 10 & Gynoecium & Ovary hairy at the apex, style $15 \mathrm{~mm}$ long, swollen areas absent. \\
\hline 11 & Fruits & Capsules 1-2 cm long, narrowly ellipsoid; seeds 4, 1.5-2 mm across, orbicular, brownish, flattened (Augustine et al. 2017). \\
\hline
\end{tabular}


flowering and seedling establishment, monocarpic species show dominance in the community.

No scientific evidence exists to explain the physiology of masting trees to synchronize the flowering through long distance and over a large area to coordinate the same cycle. Based on scientific experiments, among the three mechanisms, i.e., chemical, reproductive, and environmental, only environmental specifically climate conditions induce trees to mast synchronously over a wide range of geographical location (Isagi et al. 1997; Schauber et al. 2002). Scientific evidences propose that the periodical temperature fluctuations (probably caused by the cyclic El Nino incident) control masting with synchronization (Schauber et al. 2002). But the mechanism of this amazing phenomenon is unknown till now (Athugala 2014). A huge scope of future research is there to carry out regarding this unique phenomenon.

\section{Floral phenology}

During the second week of August, flowering starts and reaches its peak up to the third week of September (Singh and Arigela 2019). Towards the September end, flowering declines and stopped at the end of October. Flowers open within $9 \mathrm{am}$, they remain fresh up to the second day and senesced on the third day. Neelakurinji floral features facilitate pollination efficiency. Pollination may happen on the second day in the flowers that are not pollinated on the first day due to floral longevity extension. Though during the morning of the first day, most of the pollen foraged, but the flowers offer sufficient nectar to the visitors, and even on the second day, the stigma remains receptive. The number of pollinators on the second day is considerably less than the first day. On the second day, around $60 \%$ of viable pollen grains remain which may play a critical role in pollination with the help of bee (Sharma and Kuriakose Gand Shivanna 2008).

The hermaphrodite flowers are borne on racemes, which are arranged compactly. On average, each plant produces $82.5 \pm 62.5$ inflorescences and each inflorescence bears 23.8 \pm 8.8 flowers. During the peak of flowering, two to four flowers open each day in each inflorescence. After being touched by the visiting insect, anthers dehisce only. The anthers can dehisce by a gentle touch with a needle also. Anthers failed to dehisce in bagged flowers even on the second day until physical disturbance. Commercial apiculture can be successfully implemented considering its unique dehiscence. Lack of dehiscence occurs in bagged flowers due to changes in microclimate. After proper dehiscence, the anthers changed to blue (Valsaladevi and Mathew 1985; Sharma and Kuriakose Gand Shivanna 2008).

\section{Flowering periodicity}

The Nilgiri Hills means Blue Mountains and this hill range acquired the name "Nilgiri" $($ Nila $=$ Blue + Giri $=$
Mountain) because of the blue color synchronized blooming of Strobilanthes kunthiana after every 12 years (Anitha and Prasad 2007). The entire hill range looks blue once the blooming starts and retains nearly 2.5 months (Singh and Arigela 2019). Similarly, periodicities of colossal blooming were also reported in some species of Strobilanthes in East Asia and Southeast Asian countries (Kakishima et al. 2011and Kakishima et al. 2019; Tsukaya et al. 2012; Chen et al. 2019). Plietesial flowering occurs due to the adaptive evolution of floral traits, which facilitated mast seeding in some endemic Strobilanthes species of Western Ghats (Sharma and Kuriakose Gand Shivanna 2008). During its flowering season, Neelakurinji covers the Nilgiri hills like a blue carpet. Large parts of the Nilgiris are now occupied by tea plantations and dwellings (Ranjit 2003). Robinson (1935) provided a note on the periodicity of the flowering of Strobilanthes kunthiana. He mentioned 9 uninterrupted massive flowerings of S. kunthiana at an interval of 12 years in between 1838 and 1934 in Nilgiri Hills and also stated that the number of beehives increases on trees and hanging rocks. Matthew (1959) reported 5 immense flowerings in between 1910 and 1958 at 12 years interval in this region. Matthew (1971) mentioned the gregarious flowering of this species in this region in the year 1970 after 1958. Lockwood (2006) stated the mass blooming of this species in southern Western Ghats in the years 1994 and 2006. Stray flowering is also seen in this species at some places in a few small patches, but the interval between two consecutive flowerings is the same 12 years as in colossal blooming. In 2006, after a gap of 12 years, Neelakurinji flowered in other parts of Tamil Nadu and Kerala (Ian 2006). After 2006, we have seen this species in massive flowering in southern Western Ghats from the third week of October 2018 to the last week of December 2018 during my visit to Nilgiri hills. The data available from 1838 to 2018, it is clear $S$. kunthiana blooms after every 12 years and the next enormous flowering can be seen in 2030.

In botany, it is referred to as 'survival mechanism' of plants. Longer pollination helps the species to escape total destruction by predators or due to climate changes.

Secondly, being monocarpic plant, Neelakurinji reproduces once after flowering and then dies. According to Botanical Science, Neelakurinji plants have an internal calendar that helps them to study the variations or differences in day length. The plants usually record the periodical variations based on the total day length, and managers to count the exact time period for the next blossom. 'Kurinjithen' is the name of the honey, which is derived from Neelakurinji flowers. Over a wide area, enormous numbers of bees are attracted by the mass flowering, which ultimately facilitates the production of this rare honey. The availability of this honey is rare to 
the market. According to the local people, medicinal properties are there in this honey, which is beneficial for treating heart blockages, though no strong scientific report is there (Roy 2018).

\section{Fruiting}

The flowers of Neelakkurinji turn to fruits and seeds and the plants dry up after the distribution of the seeds in the same year. The seeds germinate and grow into seedlings about 700 per square meter in the following monsoon. Those that survive insects, birds, and wild animals fall into a deep slumber, growing silently and continuously, preparing themselves physically and physiologically for the next floral celebration after 12 years (Augustine Jomy 2018).

\section{Pharmacological properties}

Strobilanthes kunthiana is a rich reservoir of medicinally useful phytoconstituents. Qualitative phytochemical analysis of in vitro leaf callus confirms the presence of various secondary metabolites. Methanolic extract recorded different compounds like alkaloids, tannins, flavonoids, steroids, saponins, glycosides, phenols, and terpenoids. Both ethanolic and petroleum ether extracts showed the absence of glycosides and saponins. Chloroform extract showed positive test with alkaloids, tannins, glycosides, steroids, saponins, and phenols. Similarly, water extract showed positive to alkaloids, glycosides, tannins, phenols, and steroids. The in vitro leaf callus of $S$. kunthiana extract contains important constituent for

Table 2 Pharmacological compounds present in different extracts of S. kunthiana

\begin{tabular}{|c|c|c|}
\hline $\begin{array}{l}\text { Sr. } \\
\text { no. }\end{array}$ & Compound & Pharmacological properties \\
\hline 1 & $\begin{array}{l}\text { 2,6-bis (1,1- di-methyl ethyl)- 4-methyl } \\
\text { phenol }\end{array}$ & Antioxidant (Ibtissem et al. 2010) \\
\hline 2 & Hexadecanoic acid, methyl ester & $\begin{array}{l}\text { Antioxidant, hypocholesterolemic, nematicide, pesticide, anti-androgenic flavor, hemolytic, 5-alpha } \\
\text { reductase inhibitor, anti-fibrinolytic, lubricant, anti-alopecic (Selvan and Velavan 2015), anti- } \\
\text { inflammatory (Hema et al. 2011), cancer preventive, hepatoprotective, anti-histaminic, anti- eczemic, } \\
\text { anti-achne, anti-arthiritic, anti-coronary (Krishnamoorthy and Subramaniam 2014), anti-bacterial, anti- } \\
\text { fungal (Chandrasekaran et al. 2011) }\end{array}$ \\
\hline 3 & 9,12-Octadecadienoic acid (Z, Z) & $\begin{array}{l}\text { Anti-inflammatory, anti-arthritic, antioxidant, anti-cancer (Mangunwidjaja et al. 2006). Hypocholeste- } \\
\text { rolemic, cancer preventive, hepatoprotective, nematicide, Insectifuge, anti-histaminic, Anti-eczemic, } \\
\text { anti-acne, 5-alpha reductase inhibitor, anti-androgenic anti-coronary insectifuge (Rajeswari et al. } \\
\text { 2012). Anti-arteriosclerotic, anti- anaphylactic, anti-prostatic (Rajeswari and Srinivasan 2015). }\end{array}$ \\
\hline 4 & 9-Octadecenoic acid (Z)-, methyl ester & $\begin{array}{l}\text { Anti-inflammatory, anti-androgenic, Cancer preventive, dermatitigenic, hypo-cholesterolemic, 5-alpha } \\
\text { reductase inhibitor, anemiagenic, insectifuge (Rajeswari and Rani 2015), Antioxidant, anti-cancer } \\
\text { (Asghar et al. 2011; Hema et al. 2011) }\end{array}$ \\
\hline 5 & $\begin{array}{l}\text { Heptadecanoic acid, 16-methyl-, methyl } \\
\text { ester }\end{array}$ & $\begin{array}{l}\text { Used against skin cancer protein (Elaiyaraja and Chandramohan 2016). Anti-oxidant, anti-microbial, } \\
\text { anti-inflammatory (Vetha Merlin Kumari et al. 2016). }\end{array}$ \\
\hline 6 & Benzenesulfona mide & Anti-malarial (Andrews et al. 2013) \\
\hline 7 & Cyclotrisiloxane, hexamethyl & Anti-microbial potential, anti-oxidants (Venkatesh et al. 2014). \\
\hline 8 & $\begin{array}{l}\mathrm{N} \text {-(tert- butoxycarbonyl)-2-(4-methoxy } \\
\text { phenyl) allylamine }\end{array}$ & Phytocompound having liver susceptibility of reactions (Peter and Venky 2012). \\
\hline
\end{tabular}

9 Azulene

10 n-Nonadecanol-1

11 2,6,10-Trimethyl, 14-Ethylene-14-Pentadecne (Neophytadiene)

12 n-Hexadecanoic acid

13 2-Hexadecene,3,7,11,15-Tetramethy-,

14 4-(3,5-Di-Tert-Butyl-4-Hydroxyphenyl

15 2, Hexaceden-1- ol, 3,7,11,15-Tetramethyl (phytol)

16 1-Heptacosanol

17 1-Dodecanol

18 n-Pentadecanol

$192,6,10,14,18,22-$ Tetracosahexaene, 2,6 (Squalene)
Anti-oxidant, reduce inflammation in the skin tissue, anti-fungal, anti-bacterial and anti-septic (Steffen 1960).

Flavor and fragrance agent, anti-microbial and cytotoxicity (Dalli et al. 2007).

Enzyme inhibitor (Everlyne et al. 2015)

Artificial flavors and anti-inflammatory, anti-oxidant, hypocholesterolemic 5-alpha reductase inhibitor (Kumar et al. 2010).

Anti-bacterial activity (Everlyne et al. 2015).

Anti-oxidant (Everlyne et al. 2015).

Cosmetics, Shampoos, (antimicrobial) toilet soaps, household cleaners, and detergents (Dalli et al. 2007).

Flavor and fragrance agent, lower cholesterol, anti-microbial and cytotoxicity (Everlyne et al. 2015). Used in detergent industry, emollient, emulsifier, fragrance, flavor and anti-bacterial activity (Yogeswari et al. 2012).

Used for skin (Everlyne et al. 2015)

Anti-microbial, Synthesize cholesterol steroid hormones and vitamin d, anti-cancer and protects the skin against UV (Kelly 1999). 
pharmacological activities (Prabakaran and Kirutheka 2018). Preethi and Suseem (2014) reported antibacterial, antiviral, antifungal acute respiratory inflammation, stomach ailments, rheumatism, anxiolytic, anti-diabetic, laxative, anticancer, diuretic, anti-arthritic, antiinflammatory properties. The abundant source of unique active components shows anti-inflammatory, antiosteoarthritic (Desu et al. 2011), analgesic properties (Desu et al. 2012), anticancer activity and antioxidant (Singh et al. 2014), antibiofilm activity (Everlyne et al. 2016), enzyme inhibitor, central nervous depressant activity (Rajasekaran et al. 2000), anti-giardial activity (Singh et al. 2012) antifungal, antibacterial, antiseptic, hypocholesterolemic 5-alpha reductase inhibitor, antimicrobial, cytotoxicity, protect skin against UV (Everlyne et al. 2015). Different extracts and various herbal preparations of Neelakurinji exhibited their pharmacological potential against wide range of health issues, which is sometimes at par with usual medications. This is because of its multifaceted ethnic, ethnopharmaceutical, and ethnobotanical importance. Concise information on the compounds and their pharmacological properties of S. kuntiana has been presented in Table 2 and Fig. 3.

Strobilanthes kunthiana is a rich reservoir of medicinally useful phytoconstituents, which can be utilized for the development of traditional medicines. This implies the phytopharmaceutical importance of the plant Strobilanthes kunthiana (Singh et al. 2014; Isoe et al. 2015).

\section{Conservation status}

With the increasing intervention of the man along with the uncontrollable increase in population, which demands the space and other needs, is aggravating this problem of the existence of this wonder flower. Besides, increased pollution, natural calamities, etc., bringing the threat to biodiversity and causing endangerment to several wild species, which are also useful. The area of Neelakurinji is quite large and not protected from anthropogenic disturbances. The possible damages due to the anthropogenic disturbances such as plantations of tea, eucalyptus, black wattle, encroachments, and recently by the unbridled tourism developments and manmade summer fires are the possible

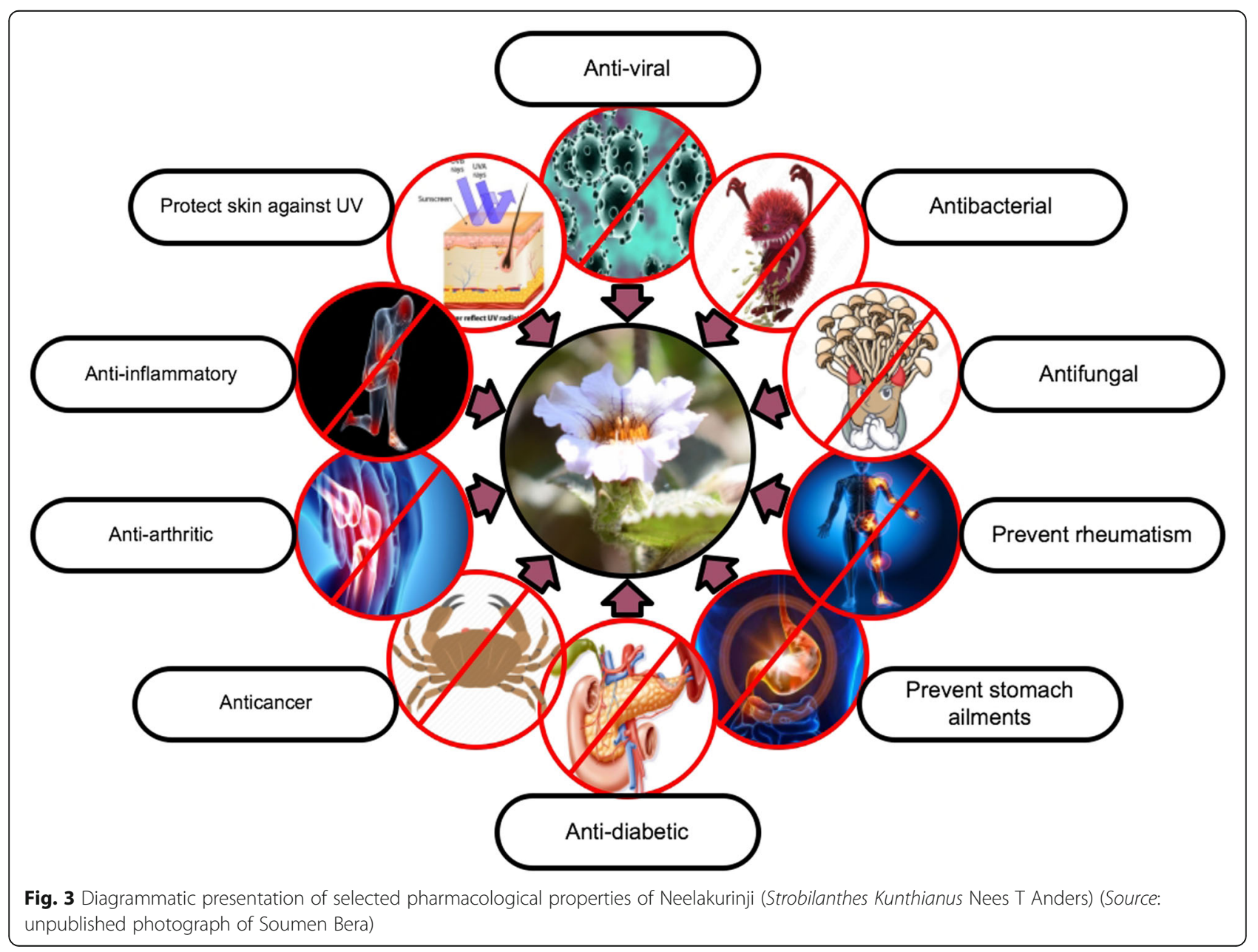


threats to this species. There may be ample justifications for all the activities like tea and eucalyptus plantations and recently tourism and encroachments. But almost all the Kurinjies are highly adapted to certain habitats without which it cannot survive. Hence, any activities that disturb the pristine nature of these grasslands and shola forests will definitely axe the population of these beautiful shrubs that have only one chance to reproduce (Augustine et al. 2017).

Based on the implementation site, broadly conservation strategies involve two approaches, i.e., in situ and ex situ. Seed gene bank and field gene bank are the different ex situ conservation approaches and in vitro gene bank, protected areas, sacred grooves, etc., are some of the examples of in situ conservation method. Based on the available resources, effort of researchers, research institutions, NGOs and communities should be coordinated for the best suitable conservation strategy (Ghosh et al. 2017).

The Government of Kerala established Kurinjimala Sanctuary in 2006 with the objective of Neelakurinji conservation along with long-term protection of the unique biodiversity of the area and the species in particular. Besides the objective of research and monitoring values associated with endemism, biodiversity, humanwildlife interaction, natural regeneration assessment and eco-restoration were also considered. This sanctuary was established to ensure that it is the first protected area of its kind in the state to be declared for the conservation of the flowering plant. Apart from being a prime habitat of Kurinji, the sanctuary is a potential habitat of an amazing variety of plant species, many of which are characteristic of the high altitude grassland. The sanctuary forms a vast stretch of high altitude shola and grassland ecosystem of high ecological, floral, faunal, and geomorphological significance. The area is also significant as an eco-sensitive landscape, which requires ecorestoration activities due to its ecological, floral, hydrological, and geomorphological importance (Department of Forests and Wildlife, Government of Kerala 2011).

\section{Conclusions}

The proper scientific reason for the synchronous blooming of Neelakurinji is not still established. So, there may be a huge scope on that for future research. An amazing flowering plant having the potentiality to convert its habitat a world tourism extravagant is not received its due importance nationally and internationally. India is blessed with a tremendous diversity of medicinal plants. But most of these medicinal plants are not properly investigated properly. We will be enriched with a large number of natural remedies for different ailments if the pharmacological properties of these plants are scientifically explored. S. kunthiana is a wonder flower domesticated predominantly at Western Ghat. Besides having rich sources of pharmacological constituents, little research priority is given to it and significantly less attempts and tools have been developed for this amazing plant to conserve. Further multidisciplinary in-depth research should be studied for further exploring its pharmaceutical quality along with efficient utilization as an attraction to the world tourism.

\section{Acknowledgements}

The authors express their sincere gratitude to the Associate Dean, College of Agriculture, Extended Campus of Bidhan Chandra Krishi Viswavidyalaya,

Burdwan, West Bengal, India for technical support.

\section{Code availability}

Not applicable.

\section{Authors' contributions}

SB carried out the conceptualization, investigation, drafting of the manuscript. SD participated in the investigation, drafting. DK participated in the investigation and helped to draft the manuscript. All authors read and approved the final manuscript.

\section{Funding}

The authors have no support or funding to report.

Availability of data and materials

Related data and material may be provided with reasonable request from the corresponding author.

Ethics approval and consent to participate

Not applicable.

\section{Consent for publication}

Not applicable.

\section{Competing interests}

The authors declare that they have no conflict of interest.

\section{Author details}

'College of Agriculture, Extended Campus of Bidhan Chandra Krishi Viswavidyalaya, Purba Bardhaman, West Bengal 713101, India. ${ }^{2}$ Department of Agronomy, Faculty of Agriculture, Bidhan Chandra Krishi Viswavidyalaya, Mohanpur, Nadia, West Bengal 741252, India.

Received: 19 May 2020 Accepted: 8 July 2020

Published online: 25 July 2020

$$
\begin{aligned}
& \text { References } \\
& \text { Andrews KT, Fisher GM, Sumanadasa SD, Skinner-Adams T, Moeker J, Lopez M, } \\
& \text { Poulsen SA (2013) Antimalarial activity of compounds comprising a primary } \\
& \text { benzene sulfonamide fragment. Bioorg Med Chem Lett 23(22):6114-6117 } \\
& \text { https://doi.org/10.1016/j.bmcl.2013.09.015 } \\
& \text { Anitha K, Prasad SN (2007) Mass flowering and pollinators of Strobilanthes } \\
& \text { consanguinea in the Western Ghats, South India. Curr Sci 92(12):1680-1681 } \\
& \text { Anonymous I (1985) Indian pharmacopoeia. Government of India, Ministry of } \\
& \text { Health and Welfare, Controller of Publications, Delhi } \\
& \text { Anonymous II (2002) Quality control methods of medicinal plant materials. WHO } \\
& \text { and A.I.T.B.S Publishers \& Distributors, Geneva and Delhi } \\
& \text { Asghar SF, Habib-ur-Rehman, Choudahry MI, Atta-ur-Rahman (2011) Gas } \\
& \text { chromatography-mass spectrometry (GC-MS) analysis of petroleum ether } \\
& \text { extract (oil) and bio-assays of crude extract of Iris germanica. Int J Gen Mol } \\
& \text { Biol 3(7):95-100 } \\
& \text { Athugala Y (2014) Synchronized flowering and masting behavior of Strobilanthes } \\
& \text { (nelu). Sciscitator } 1 \\
& \text { Augustine J (2008) Genus Strobilanthes in High Ranges of Kerala: diversity, } \\
& \text { distribution and endemism. In: Rawat GS (ed) Special habitats and } \\
& \text { threatened plants of India. ENVIS Bulletin: Wildlife and Protected Areas. Vol. } \\
& \text { 11(1). Wildlife Institute of India, Dehradun, pp 136-146 } \\
& \text { Augustine J (2018) Twinkling Blue: The Saga of Strobilanthes. Aranyam } \\
& \text { neelakurinji special, pp 8-11 }
\end{aligned}
$$


Augustine J, Josekutty EJ, Biju P (2017) Strobilanthes sainthomiana: A new species of Strobilanthes Blume (Acanthaceae) from Western Ghats, India. Taiwania 62(1):63-66

Balandrin MF, Kinghorn AD, Farnsworth NR (1993) Plant-derived natural products in drug discovery and development: an overview. In: Kinghorn AD, Balandrin MF (eds) Human medicinal agents from plants. American Chemical Society. ACS Symposium Series, Washington, DC, pp 2-12 https://doi.org/10.1021/bk1993-0534.ch001

Bhat DM, Murali KS (2001) Phenology of understorey species of tropical moist forest of Western Ghats region of Uttara Kannada district in South India. Curr Sci 81:799-805

Bremekamp CEB (1944) Materials for a monograph of the Strobilanthinae (Acanthaceae). Verhandelingen der Nederlandsche Akademic van Wetenschappen, Afdeeling Natuurkunde. Tweede Sectie 41:1-306

Carine MA, Alexander JM, Scotland RW (2004) A revision of the Strobilanthes kunthiana-group (Phlebophyllum sensu Bremekamp)(Acanthaceae). Kew Bulletin 1:1-25 https://doi.org/10.2307/4111071

Chandrasekaran M, Senthilkumar A, Venkatesalu V (2011) Antibacterial and antifungal efficacy of fatty acid methyl esters from leaves of Sesuvium portulacastrum L. Eur Rev Med Pharmcol Sci 15(7):775-780

Chen F, Deng Y, Xiong Z, Ran J (2019) Strobilanthes hongii, a new species of Acanthaceae from Guizhou, China. Phytotaxa 388(1):135-144

Dalli AK, Saha G, Chakraborty U (2007) Characterization of Antimicrobial compounds from a common fern, Pterin biaurita. Indian J Exp Biol 45:285290

Daniel TF (2006) Synchronous flowering and monocarpy suggest plietesial life history for neotropical Stenostephanus chiapensis (Acanthaceae). California Acad Sci 7:1011-1018

Department of Forests and Wildlife, Government of Kerala (2011) First management plan of Kurinjimala sanctuary 2011-2012 to 2020-2021

Desu BSR, Elango K, Satish Kumar MN, Suresh B, Manimaran S, Nanjan MJ (2011) In- vitro anti-inflammatory and anti- osteoarthritic activities of Strobilanthes kunthianus and Strobilanthes cuspidatus. Int J Res Pharm Biomed Sci 1(4): 2231-2781

Desu BSR, Elango K, Satish Kumar MN, Suresh B, Manimaran S, Nanjan MJ (2012) Analgesic activity of Strobilanthes kunthianus and Strobilanthes cuspidatus. Int J Res Pharm Biomed Sci 3(1):2229-3701

Elaiyaraja A, Chandramohan G (2016) Comparative phytochemical profile of Crinum defixum Ker-Gawler leaves using GC-MS. Asian J Pharm Res Dev 4(3): 1-13 https://doi.org/10.18052/www.scipress.com/ILNS.46.8

Everlyne IM, Darsini DTP, Yadav SA (2016) Unraveling antibiofilm potency of Strobilanthes kunthiana Nees T. Anderson ex Benth against throat-infectious methicillin-resistant Staphylococcus aureus. Indo American J Pharm Res 6(6): $5707-5716$

Everlyne IM, Sangilimuthu AY, Darsini DTP (2015) Spectral analyses of the bioactive compounds present in the ethanolic leaf extract of Strobilanthes kunthiana (Nees) T Anderson ex Benth. Adv Biores 6(3):65-71

Ghosh S, Ganga M, Ratna Priyanka R, Manimaran P (2017) Endangered ornamental plant species in India and strategy for their conservation. A Chem Sci Rev Lett 6(23):1457-1464

Guptha AK, Neeraj T, Sharma M (2005) Quality standards of Indian medicinal plants. ICMR 3:9-19

Hema R, Kumaravel S, Alagusundaram K (2011) GC/MS determination of bioactive components of Murraya koenigii. J American Sci 7(1):80-83

lan L (2006) Kurinji crown Frontline September 8, pp 66-72

Ibtissem B, Imen M, Souad S (2010) Dosage of 2, 6-bis (1.1-dimethylethyl)-4methyl phenol (BHT) in the plant extract Mesembryanthemum crystallinum. Biomed Biotechnol 5:1-5 https://doi.org/10.1155/2010/142486

Isagi Y, Sugimura K, Sumida A, Ito H (1997) How does masting happen and synchronize? J Theor Biol 187(2):231-239

Isoe ME, Alagar YS, Deivamarudachalam TPD (2015) Spectral analyses of the bioactive compounds present in the ethanolic leaf extract of Strobilanthes kunthiana (Nees) T Anderson ex Benth. Adv Biores 6(3):65-71 https://doi.org/ 10.15515/abr.0976-4585.6.3.6571

Kakishima S, Liang YS, Ito T, Yang TYA, Lu PL et al (2019) Evolutionary origin of a periodical mass flowering plant. Ecol Evol 2019:1-9

Kakishima S, Yoshimura J, Murata H, Murata J (2011) 6-Year periodicity and variable synchronicity in a mass-flowering plant. PLOS ONE 6(12):e28140 https://doi.org/10.1371/journal.pone.0028140
Karthikeyan S, Sanjappa M, Moorthy S (2009) Flowering plants of IndiaDicotyledons (Acanthaceae- Avicenniaceae), Vol. 1. Botanical Survey of India, Kolkata, p 365

Kelly GS (1999) Squalene and its potential clinical uses. Alternative Med Rev 4(1): 29-36 Pubmed

Krishnamoorthy K, Subramaniam P (2014) Phytochemical profiling of leaf, stem, and tuber parts of Solena amplexicaulis (Lam.) Gandhi using GC-MS. Int Sch Res Notices 2014:1-13 https://doi.org/10.1155/2014/567409

Kumar PP, Kumaravel S, Lalitha C (2010) Screening of Vitex negundo. African J Biochem Res 4:191-195

Lockwood I (2006) Kurinji crown. Frontline 23:66-72

Mabberley DJ (2017) Mabberley's Plant-Book (4th Edition)

Mangunwidjaja DS, Kardono SR, Iswantini LBSD (2006) Gas chromatography and gas chromatography-mass spectrometry analysis of Indonesian Croton tiglium seeds. J Applied Sci 6(7):1576-1580. https://doi.org/10.3923/jas.2006. 1576.1580

Matthew KM (1959) The vegetation of Kodaikanal grassy slopes. J Bombay Nat Hist Soc 56:387-422

Matthew KM (1971) The flowering of the Strobilanthus (Acanthaceae). J Bombay Nat Hist Soc 67:502-506

McDonald MB, Kwong, FY (2005). Flower seeds: biology and technology. CABI.

Moylan EC, Bennett JR, Carine MA, Olmstead RG, Scotland RW (2004) Phylogenetic relationships among Strobilanthes (Acanthaceae): Evidence from ITS nrDNA, trnL-F cpDNA, and morphology. Am J Bot 91(5):724-735. https:// doi.org/10.3732/ajb.91.5.724

Paulsamy S, Vijayakumar KK, Murugesan M, Padmavathy S, Senthilkumar P (2007) Ecological status of medicinal and other economically important plants in the shola understories of Nilgiris, the Western Ghats. Nat Prod Radiance 6(1): $55-61$

Peter PJ, Venky VM (2012) Phytochemical and GC-MS studies Onindigofera linnaei Linn. Int J Phytopharm Res 2(5):143-148. https://doi.org/10.7439/ijpp.v2i5.615

Prabakaran R, Kirutheka E (2018) GCMS, phytochemicals and antioxidant activities of in vitro callus extracts of Strobilanthes kunthiana (Nees) T. Anderson ex Benth: An endemic plant of Acanthaceae. Brazilian J Biol Sci 5(10):359-372

Preethi F, Suseem SR (2014) A comprehensive study on an endemic Indian genus-Strobilanthes. Int J Pharmacogn Phytochem Res 6:459-466

Rajapakse N, Wijesundara S, Bandaranayake P 2018. Taxonomic Account of Strobilanthes sp. in Sri Lanka. Proceedings of the 23rd International Forestry and Environment Symposium 2018 of the Department of Forestry and Environmental Science, University of Sri Jayewardenepura, Sri Lanka. Biodiversity and Ecological Health

Rajasekaran A, Loganathan V, Jaewanth A (2000) Jayakar B (2000) Central nervous activity of Strobilanthes kunthiana leaf. Hamdard Medicus 43(1):38-40

Rajeswari B, Srinivasan M (2015) GC-MS analysis of bioactive components from the ethanolic leaf extract of Flueggea leucopyrus Wild. Int J Pharm Sci Rev Res 33(1):270-273

Rajeswari G, Murugan M, Mohan VR (2012) GC- MS analysis of bioactive components of Hugonia mystax L. (Linaceae). Res J Pharm Biol Chem Sci 3(4) 301-308

Rajeswari J, Rani S (2015) GC-MS analysis of phytochemical compounds in the ethanolic extract of root of Lawsonia inermis Linn. Int J ChemTech Res 7(1): 389-399

Ranjit DRJ (2003) Impact of tea cultivation on anurans in the Western Ghats. Curr Sci 85(10):1415-1422

Robinson ME (1935) The flowering of Strobilanthes in 1934. J Bombay Nat Hist Soc 38:117-122

Roy M (2018) Kurinji: The flower of blue mountains. Mariyakutty Mathew Foundation, Kalayanthani, Thodupuzha, Kerala India

Schauber EM, Kelly D, Turchin P, Simon C, Lee WG et al (2002) Masting by eighteen New Zealand plant species: the role of temperature as a synchronizing cue. Ecol 83(5):1214-1225

Selvan PS, Velavan S (2015) Analysis of bioactive compounds in methanol extract of Cissus vitiginea leaf using GC-MS technique. Rasayan J Chem 8(4):443-447

Sharma MV, Kuriakose Gand Shivanna KR (2008) Reproductive strategies of Strobilanthes kunthianus, an endemic, semelparous species in southern Western Ghats, India. Bot J Linn Soc 157:155-163

Singh B, Das S, Maithi A (2014) Antioxidant property for lipophilic extract of Strobilanthes kunthiana flowers. Indian J Res Pharma Biotechnol 2(1):1005-1009

Singh DN, Verma N, Kulshreshtha DK, Agrawal AK (2012) In-vitro antigiardial activity of ethanolic extract and fractions from Phlebophyllum kunthianum. J Nat Remed 12(1):68-71 
Singh RK, Arigela RK (2019) Gregarious flowering of two endemic Strobilanthes species (Acanthaceae) in southern Western Ghats, India and typification of two names. NeBIO 10(4):227-232

Singh RK, Diwakar PG (2007) Gregarious flowering of Strobilanthes callosus Nees in Western Ghats. Indian J For 30:553-555

Steffen A (1960) Perfume and flavor materials of natural origin. Elizabeth, New Jersey, pp 157-158

Tsukaya H, Kakishima S, Hidayat A, Murata J, Okada H (2012) Flowering phenology of the nine-year plant, Strobilanthes cernua (Acanthaceae). Tropics 20:79-85

Tsvuura Z, Griffiths ME, Gunton RM, Lawes MJ (2011) Predator satiation and recruitment in a mast fruiting monocarpic forest herb. Ann Bot 107(3):379387

Valsaladevi G, Mathew PM (1985) Pollen morphology of Strobilanthes kunthianus. Curr Sci 54(7):349-350

Venkatesh R, Vidya R, Kalaivani K (2014) Gas chromatography and mass spectrometry analysis of Solanum villosum (Mill) (Solanaceae). Int J Pharm Sci Res 5(12):52-83

Venu P (2006) Strobilanthes Blume (Acanthaceae) in Peninsular India Kolkata. Botanical survey of India. pp, India, p 216

Vetha Merlin Kumari H, Manickavasakam K, Mohan S (2016) GC-MS analysis of bioactive components of a siddha poly herbal drug Adathoda chooranam. Int J Res Ayurveda Pharm 7(2):4-7. https://doi.org/10.7897/2277-4343.07245

Wallich N (1830). A numerical list of dried specimens of plants in the East India Company's Museum. London. pp. 71

Yogeswari S, Ramalakshmi S, Neelavathy R, Muthumary J (2012) Identification and comparative studies of different volatile fractions from Monochaetia kansensis by GCMS. Global J Pharmacol 6(2):65-71

\section{Publisher's Note}

Springer Nature remains neutral with regard to jurisdictional claims in published maps and institutional affiliations.

\section{Submit your manuscript to a SpringerOpen ${ }^{\circ}$ journal and benefit from:}

- Convenient online submission

- Rigorous peer review

- Open access: articles freely available online

High visibility within the field

- Retaining the copyright to your article

Submit your next manuscript at $\boldsymbol{\nabla}$ springeropen.com 